\title{
RUSSIAN BANKS IN NOVEMBER 2013: VOLATILE MARKET LEADS TO REDISTRIBUTION OF ASSETS IN FAVOR OF MAJOR BANKS
}

\author{
M.Khromov
}

The dynamics of basic development indicators in the banking sector in November 2013 was governed by the most notorious event of the month in the banking sector, i.e., revocation of the license of Master Bank. The event triggered redistribution of assets and the customer base in favor of major banks, above all, state controlled ones.

Indeed, revocation of the banking license of Master Bank became, the main event in the market of banking services in November 2013. While it is not within the scope of this review to discuss this decision of the Bank of Russia, we will try to analyze its effect on the dynamics of the Russia's banking sector development.

As of 1 November 2013, Master Bank's assets totaled $\mathrm{Rb} 86 \mathrm{bn}$, less than $0.2 \%$ of the total bank's assets as of the same date. Master Bank used to play an important role in the retail banking sector, where its share reached $0.3 \%$ of the total retail accounts and deposits, while its liabilities on retail deposits amounted to $\mathrm{Rb} 47 \mathrm{bn}$. Therefore, the direct effect of the bank's banking license revocation was found to be insignificant. This factor triggered a 0.2 p.p. decline in the assets and a 0.3 p.p. fall in the deposits of the banking sector in November 2013. Furthermore, most of the retail deposits will be available to their owners as early as in December 2013 and return in part to the accounts and deposits in other banks.

More prominent was an indirect effect of the Master Bank's banking license revocation. The effect was evident mostly through started redistribution of customers from small banks to larger banks, above all, state-owned banks. This effected both bank assets and liabilities.

The total assets in the banking sector increased ${ }^{1}$ $1.5 \%, 1.7 \%$ net of the Master Bank's banking license revocation, in November 2013. Therefore, net of the Master Bank banking license revocation event, one could say that the trend towards faster growth rates in bank assets remained unchanged. Annual growth rates at the November 2013 month-end stood at 16.0\%, having reached a new lowest year-to-month value.

Thirty-top banks's assets gained $2.5 \%$ during the month while Sberbank's and major state-owned banks' total assets increased ${ }^{2} 2.9 \%$. The both values

1 Hereinafter, unless otherwise indicated, growth rates in balance sheet figures are presented with allowance for revaluation of the foreign currency component.

2 This group comprises the banks within the VTB Group: VTB, VTB24, Bank of Moscow, and Transcreditbank (until November 1, 2013, when it merged with VTB24), as well as Gazprombank and Russian Agricultural Bank.

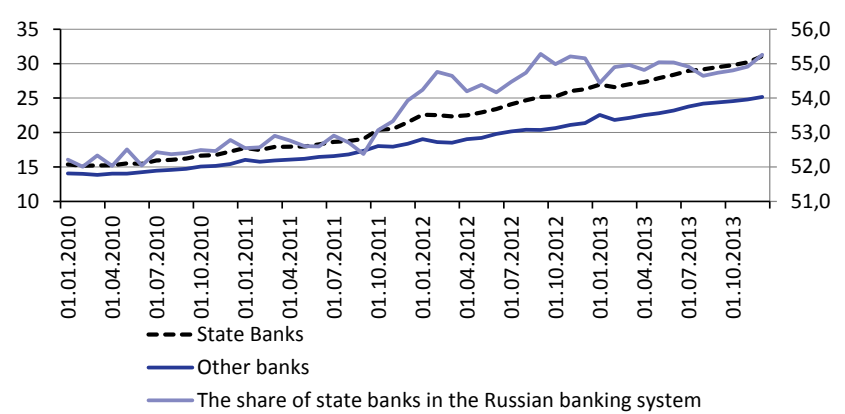

Fig. 1. Dynamics of state banks' and other banks' assets (trillions of rubles), and the share of state banks in the assets (\%, right-hand scale)

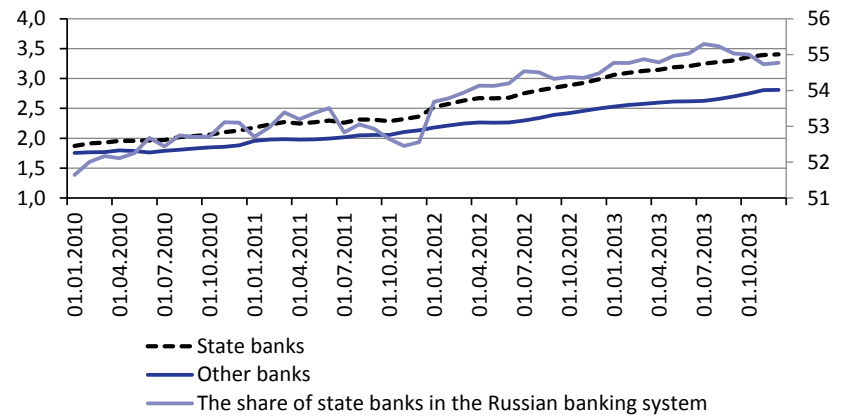

Fig. 2. Dynamics of state banks' and other banks' equity capital $^{1}$ (trillions of rubles), and state banks' equity stake (\%, right-hand scale)

reached their year-to-month highest. Unlikewise, in November 2013 the assets of small and medium-sized banks, outside the 30 -top banks, shrank $1.6 \%$, or $1.0 \%$ net of the Master Bank's banking license revocation, for the first time since the January seasonal slowdown.

In November 2013, the banking sector's equity increased insignificantly $0.3 \%$, or $0.4 \%$ net of Master Bank. The dynamics of equity was not governed by the effect of the Master Bank's banking license revocation, and, instead, medium-sized and small banks' equity growth rate ( $0.7 \%$ net of Master Bank) happened to be higher than in major banks (0.3\%). The share of stateowned banks' capital remained unchanged during the month.

3 Calculated according to balance-sheet accounts (form No. 101). 
The banking sector's profit reached its lowest (Rb 64bn) in November 2013 over the past two years. The average monthly profit amounted to $\mathrm{Rb} 84 \mathrm{bn}$ in 2012 and $\mathrm{Rb} 82 \mathrm{bn}$ over the first 10 months in 2013. Furthermore, profit before loan loss provisions dropped lowest (Rb 81bn) over the period of 2012 thru 2013. The return on banking sector's equity dropped to $12 \%$ p.a. in November 2013. The corresponding value of this indicator stood at $17 \%$ in the period of January thru October 2013.

\section{Fundraising}

Retail bank savings in November 2013 increased $0.6 \%$ (Rb 98bn), or $0.9 \%$ net of Master Bank. Annual growth rates dropped to $18.6 \%$. In November 2013, deposits inflow growth rate was much more intensive in major banks: $1.9 \%$ (Rb 222bn), while major stateowned banks saw even a higher growth rate in deposits inflow: $2.4 \%$ (Rb 225bn). There were two banks, namely Sberbank and VTB24, which attracted most of the deposit inflow in November 2013, altogether these banks attracted $\mathrm{Rb} 209 \mathrm{bn}$ of the deposits. In the same month small and medium-sized banks came up $\mathrm{Rb} 124 \mathrm{bn}$ (3.2\%) or $2.0 \%$ short, and $\mathrm{Rb} 77 \mathrm{bn}$ net of Master Bank. Therefore, it was state-owned banks that were the key beneficiaries of instability.

In November 2013, the amount of corportate bank accounts increased $2.3 \%$ while annual growth rates increased a bit from $11.7 \%$ to $13.7 \%$. However, customers migrated to major banks. The top-30 banks in terms of assets gained 3.5\% ( $\mathrm{Rb} 325 \mathrm{bn}$ ) from corporae customers while state-owned banks gained 3.8\% ( $\mathrm{Rb} 234 \mathrm{bn}$ ), whereas small and medium-sized banks come up 1.4\% (Rb 42bn) short of corporate customers resources, or $1.0 \%$ (Rb 30bn) net of Master Bank.

Banks' debt to the monetary authorities (the Bank of Russia and Ministry of Finance of Russia) reached another record value in nominal terms. For instance, banks' total debt to to the Bank of Russia increased $\mathrm{Rb} 408 \mathrm{bn}$ to $\mathrm{Rb} 3707 \mathrm{bn}$ during the month, having exceeded the highest value which was observed during the crisis ( $\mathrm{Rb} 3653 \mathrm{bn}$ ).

Unlikewise, the amount of the Ministry of Finance's deposits with commercial banks declined $\mathrm{Rb} 315 \mathrm{bn}$ in November 2013 due to a seasonal increase in public expenses which is traditional for the year end.

As a result, commercial bank's total volume of debt to the Bank of Russia and the Ministry of Finance of Russia increased $\mathrm{Rb}$ 93bn to reach $\mathrm{Rb} 4324 \mathrm{bn}$. The current situation differs from the crisis values of state support only in relative measures. At that time (as of 01.02.2009), the banking sector's liabilities to the monetary authorities amounted to $\mathrm{Rb} 3654 \mathrm{bn}$ or accounted for $12.3 \%$ of the total assets available in the

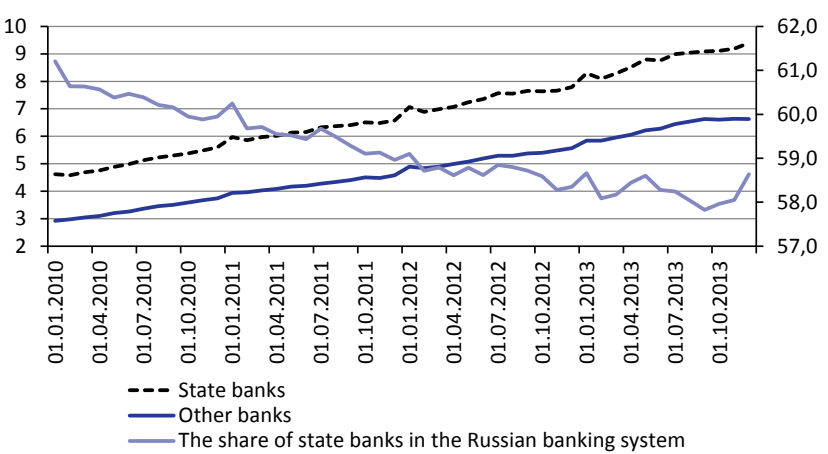

Fig. 3. Dynamics of state banks' and other banks' retail deposits (trillions of rubles), and the share of state banks in the retail deposit market (\%, right-hand scale)

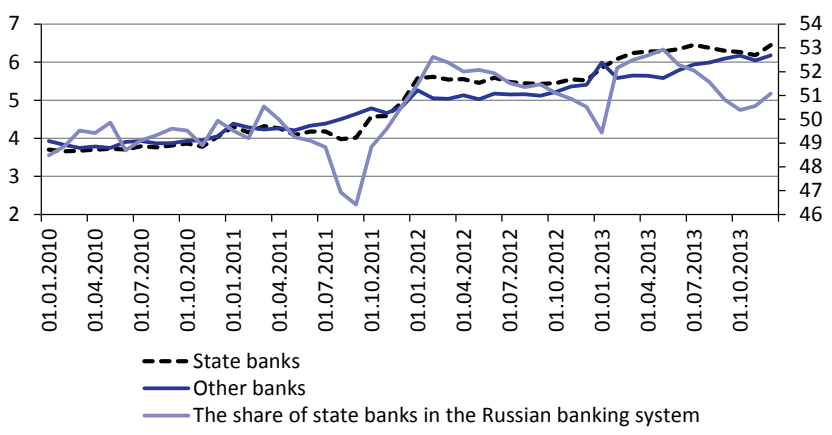

Fig. 4. Dynamics of corporate accounts with state and other banks (trillions of rubles), and the share of state banks in the corporate account market (\%, right-hand scale)

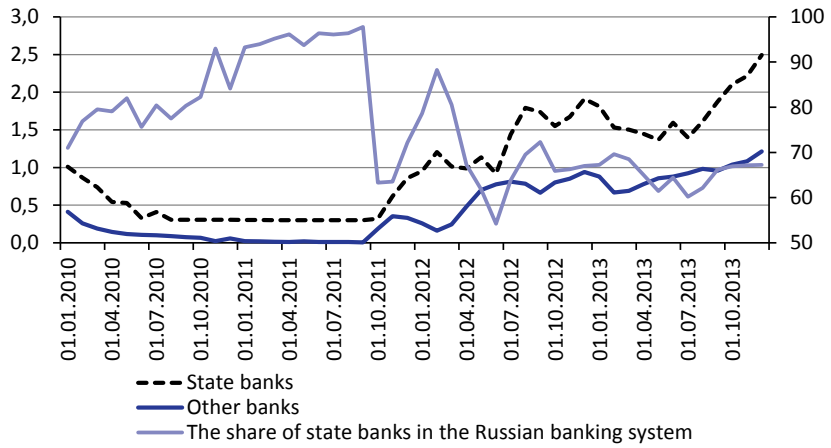

Fig. 5. Dynamics of Bank of Russia's loans extended to state banks and other banks (trillions of rubles), and the share of state banks in Bank of Russia's loans. (\%, right-hand scale)

banking sector. Today, the resources received by banks from the monetary authorities account for $7.7 \%$ of the total assets available in the banking sector.

\section{Loans issued}

Households' loan debt to banks increased 1.5\% (Rb 151bn) in November 2013. This indicator's annual growth rates kept falling, as far as to $28.2 \%$ as of 01.12 .2013 (39.1\% as of the beginning of the year).

In addition, the retail loan market saw a trend towards customer migration from small to major banks 
Table 1

RUSSIAN BANKING SYSTEM'S STRUCTURE OF LIABILITIES (AT MONTH END), AS PERCENTAGE OF TOTAL

\begin{tabular}{|c|c|c|c|c|c|c|c|c|c|c|c|c|}
\hline & 12.08 & 12.09 & 12.10 & 12.11 & 06.12 & 12.12 & 03.13 & 07.13 & 08.13 & 09.13 & 10.13 & 11.13 \\
\hline Liabilities, billions of rubles & 28022 & 29430 & 33805 & 41628 & 44266 & 49510 & 49839 & 53353 & 53876 & 54348 & 54981 & 56259 \\
\hline Equity & 14.1 & 19. 3 & 18.7 & 16. 9 & 16. 8 & 16.2 & 16. 7 & 16.3 & 16. 3 & 16. 5 & 16. 5 & 16. 2 \\
\hline Loans from the Bank of Russia & 12. 0 & 4. 8 & 1. 0 & 2. 9 & 5. 1 & 5.4 & 4. 5 & 4. 9 & 5.3 & 5.8 & 6.0 & 6.6 \\
\hline Interbank operations & 4. 4 & 4. 8 & 5.5 & 5.7 & 4. 8 & 5. 6 & 5. 4 & 5. 1 & 5. 1 & 5. 1 & 5.2 & 5.4 \\
\hline Foreign liabilities & 16. 4 & 12. 1 & 11.8 & 11. 1 & 11.3 & 10.8 & 10.4 & 10.6 & 10. 4 & 10. 1 & 10. 0 & 10. 3 \\
\hline Retail accounts and deposits & 21.5 & 25. 9 & 29. 6 & 29. 1 & 29.4 & 28.9 & 29.6 & 29.6 & 29.6 & 29. 3 & 29. 2 & 28. 9 \\
\hline Corporate accounts and deposits & 23.6 & 25.9 & 25. 7 & 26. 0 & 24.0 & 24 & 23. 9 & 23.2 & 23. 0 & 22. 9 & 22.3 & 22.4 \\
\hline $\begin{array}{l}\text { Accounts and deposits of gov- } \\
\text { ernment agencies and local } \\
\text { government authorities }\end{array}$ & 1. 0 & 1. 0 & 1. 5 & 2. 3 & 1. 5 & 1. 6 & 1. 4 & 2. 6 & 2. 7 & 2. 9 & 3. 2 & 2. 6 \\
\hline Outstanding securities & 4. 1 & 4. 1 & 4. 0 & 3. 7 & 4. 5 & 4. 9 & 5.2 & 4. 9 & 4. 9 & 4. 7 & 4. 8 & 4. 7 \\
\hline
\end{tabular}

Source: Central Bank of Russia, IET's estimates.

in November 2013. The household loans growth rate reached $3.4 \%$ ( $R b 260 \mathrm{bn}$ ), a record value since the summer of 2012, in the 30-top banks while $4.7 \%$ ( $\mathrm{Rb} 249 \mathrm{bn}$ ) in state-owned banks. Furthermore, during the month small and medium-sized banks lost $4.1 \%$ of their retail credit portfolio (Rb $109 \mathrm{bn}$ ) or $3.7 \%$, and $\mathrm{Rb} 98 \mathrm{bn}$ net of Master Bank. Therefore, this bank services market was also governed by domination of major state-owned banks in November 2013.

The retail segment quality of the bank credit portfolio remained unchanged in terms of formal indicators in November 2013. Overdue debt kept accounting for $4.6 \%$ of the total lending receivables. The ratio of loan loss provisions to lending receivables stood at $7.2 \%$. State-owned banks kept showing the best quality of loans in terms of overdue debt. As of 01.12.2013, for instance, Sberbank, other state-owned banks, and small and medium-sized banks had a $2.1 \%, 4.6 \%$, and $5.9 \%$ share of overdue debt respectively. The worst quality of retail loans was observed in major non-state banks, including foreign banks (6.7\%). Furthermore, this group of banks also includes the leading lenders of unsecured consumer loans such as Home Credit Bank (with a $13.8 \%$ share of debt) and Russkiy Standard Bank (12.2\%). Both banks account for $5 \%$ of the total retail loans and $15 \%$ of the overdue debt.

In November 2013, the amount of outstanding debt due by corporate customers on bank loans increased $0.9 \%$ ( $\mathrm{Rb} 178 \mathrm{bn}$ ) or $1.1 \%$ ( $\mathrm{Rb} 230 \mathrm{bn}$ ) net of Master Bank. Annual growth rates at the November 2013 month-end stood at $13.7 \%$, being approximately equal to the corresponding value which was observed during the previous four months.

The corporate lending market happened to be the only one which saw no migration of customers from small to major banks in November 2013. Formally, loan growth rate in small and medium-sized banks $(-0.1 \%)$ was markedly behind the value of the corresponding

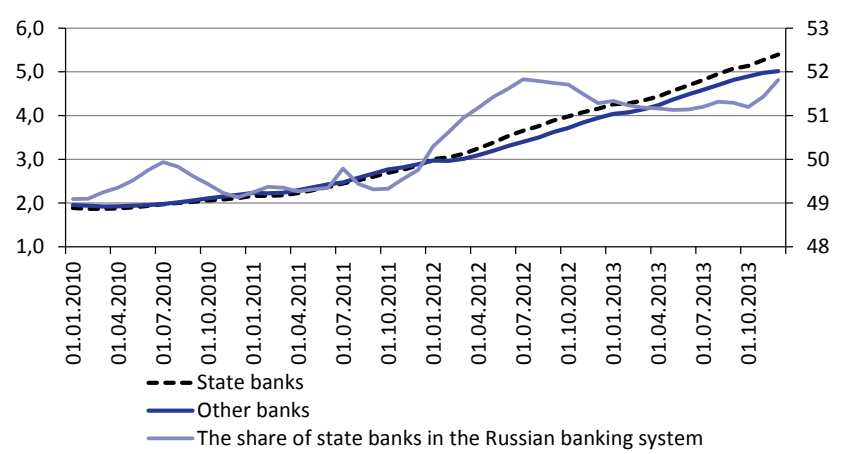

Fig. 6. Dynamics of state banks' and other banks' retail loans (trillions of rubles), and the share of state banks in the retail loan market (\%, right-hand scale)

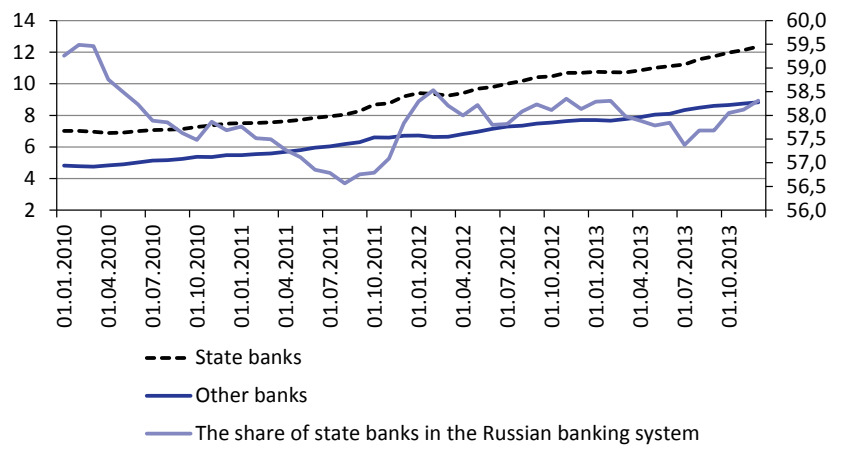

Fig. 7. Dynamics of state banks' and other banks' corporate loans (trillions of rubles), and the share of state banks in the corporate loan market (\%, right-hand scale)

indicator in the 30-top banks (1.1\%). In fact, the difference can be explained by "dropout" of Master Bank. Net of Master Bank, growth rate in the debt due by corporate customers to medium-sized and small banks would have shown the same $1.1 \%$.

The corporate segment of credit portfolio remained almost the same in November 2013. Overdue debt remained at $4.3 \%$. The ratio of loan loss provisions to total lending receivables shrank from $7.1 \%$ to $7.0 \%$. 
Table 2

RUSSIAN BANKING SYSTEM'S STRUCTURE OF ASSETS (AT MONTH END), AS PERCENTAGE OF TOTAL

\begin{tabular}{|l|c|c|c|c|c|c|c|c|c|c|c|c|c|}
\hline & 12.08 & 12.09 & 12.10 & 12.11 & 06.12 & 12.12 & 04.13 & 07.13 & 08.13 & 09.13 & 10.13 & 11.13 \\
\hline Assets, billions of rubles & 28022 & 29430 & 33805 & 41628 & 44266 & 49510 & 50693 & 53353 & 53876 & 54348 & 54981 & 56259 \\
\hline Cash and precious metals & 3.0 & 2.7 & 2.7 & 2.9 & 2.5 & 3.1 & 2.7 & 2.3 & 2.3 & 2.3 & 2.3 & 2.2 \\
\hline Deposits in the Bank of Russia & 7.5 & 6.9 & 7.1 & 4.2 & 3.0 & 4.4 & 3.0 & 3.0 & 2.9 & 3.5 & 3.1 & 3.0 \\
\hline Interbank operations & 5.2 & 5.4 & 6.5 & 6.4 & 5.8 & 6.8 & 6.1 & 5.9 & 5.8 & 5.8 & 6.0 & 6.1 \\
\hline Foreign assets & 13.8 & 14.1 & 13.4 & 14.3 & 14.2 & 13.0 & 15.0 & 15.0 & 14.5 & 13.6 & 13.4 & 13.7 \\
\hline Retail sector & 15.5 & 13.1 & 13.0 & 14.4 & 16.0 & 16.8 & 17.7 & 18.1 & 18.4 & 18.5 & 18.7 & 18.5 \\
\hline Corporate sector & 44.5 & 44.5 & 43.6 & 44.0 & 43.6 & 41.3 & 41.5 & 41.0 & 41.1 & 41.2 & 41.5 & 41.0 \\
\hline State & 2.0 & 4.2 & 5.1 & 5.0 & 3.8 & 3.2 & 2.9 & 3.4 & 3.0 & 2.9 & 3.1 & 3.0 \\
\hline Property & 1.9 & 2.7 & 2.6 & 2.3 & 2.3 & 2.2 & 2.2 & 2.1 & 2.1 & 2.1 & 2.1 & 2.1 \\
\hline
\end{tabular}

Source: Central Bank of Russia, IET's estimates.

With regard to the groups of banks under review, the best quality of corporate loan receivables remained at medium-sized and small banks, where the share of overdue debt was $2.8 \%$ as of 01.12 .2013 . The worst quality was shown by major state-owned banks net of Sberbank (6.8\%), where a high level of the overdue debt was caused by an extremely poor quality of the Bank of Moscow's credit portfolio (23.5\%). 